\title{
Д.П. ФЕДУЛКИН,
}

советник по интеллектуальной собственности ФГБНУ «Дирекция НТП» Минобрнауки России, г. Москва, Россия, dfedulkin@fcntp.ru

\section{В.Г. ЗИНОВ,}

д.э.н., главный научный сотрудник Центра научно-технической экспертизы ИПЭИ РАНХиГС при Президенте РФ, г. Москва, Россия, zinov-v@yandex.ru

\section{ПРОБЛЕМЫ УПРАВЛЕНИЯ ПРАВАМИ НА РЕЗУЛЬТАТЫ ИНТЕЛЛЕКТУАЛЬНОЙ ДЕЯТЕЛЬНОСТИ, СОЗДАННЫМИ С ИСПОЛЬЗОВАНИЕМ БЮДЖЕТНЫХ СРЕДСТВ ${ }^{1,2}$}

\footnotetext{
УДК 338.28

Федулкин Д.П., Зинов В.Г. Проблемы управления правами на результаты интеллектуальной деятельности, созданными с использованием бюджетных средств (ФГБНУ «Дирекция НТП» Минобрнауки России, ул. Пресненский Вал, д. 19, стр. 1, г. Москва, Россия, 123557; Центр научно-технической экспертизы ИПЭИ РАНХиГС при Президенте РФ, пр. Вернадского, д. 82, г. Москва, Россия, 119571)

Аннотация. В статье анализируются проблемы, возникающие при коммерциализации научных результатов, полученных с использованием бюджетных средств, в связи с нерешенностью ряда принципиальных вопросов управления правами на такие результаты интеллектуальной деятельности. Выявлены правовая неопределенность соглашения о предоставлении субсидии для бюджетного финансирования исследований и отсутствие единой методологии управления правами Российской Федерации на полученные научнотехнические результаты. Авторы показали, что значительные бюджетные средства, направляемые на исследования в рамках проектов полного жизненного цикла, в отсутствии кодифицированного свода правил создания интеллектуальной собственности, вызывают серьезные по масштабу влияния проблемы на пути успешного научно-технологического развития страны.

В качестве реальных мер по преодолению причин, являющихся источником рисков реализации амбициозных планов научно-технологического развития экономики, авторы предлагают разработать и принять единые правила, определяющие принципы и меры по управлению правами на результаты интеллектуальной деятельности, начиная от формирования заказа, условий и оснований распределения прав на результать интеллектуальной деятельности, а также наделяющий ФОИВы всей полнотой полномочий и ответственности в системе государственной политики. Предлагаемый подход необходим при обосновании обязательств по доведению разработок до стадии промышленного применения и реализации готовой продукции, а также обязательств по мониторингу использования результатов интеллектуальной деятельности и принятию решений об обоснованности поддержания их правовой охраны.

Ключевые слова: научно-технологическое развитие, создание интеллектуальной собственности за счет государственных средств, управление интеллектуальной собственностью, кодификация правил, соглашения, субсидии, гранты.

DOI 10.22394/2410-132Х-2019-5-1-40-66

I Цитирование публикации: Федулкин Д.П., Зинов В.Г. (2019) Проблемы управления правами на результаты I интеллектуальной деятельности, создаваемые с использованием бюджетных средств // Экономика науки. Т. 5. № 1. С. 40-66.
}

1 Публикация подготовлена по результатам научно-исследовательской работы № 1.2 «Разработка подходов к таргетированию крупных компаний Российской Федерации в качестве субъекта технологического развития страны» государственного задания РАНХиГС на 2019 год.

2 Публикация подготовлена на основании результатов, полученных в рамках выполнения работы по государственному заданию на 2018 г. и плановый период 2019 и 2020 гг. по теме: «Организационно-техническое обеспечение мероприятий федеральной целевой программы «Исследования и разработки по приоритетным направлениям развития научно-технологического комплекса России на 2014-2020 годы» (соглашение от 30.03.2018 № 074-03-2018-344).

(с) Д.П. Федулкин, В.Г. Зинов, 2019 г. 


\section{ВВЕДЕНИЕ}

Совокупностью Указов Президента Российской Федерации от 01.12.2016 г. № 642 [1] и от 07.05.2018 г. № 204 [2] была создана новая система координат для российского сектора исследований и разработок. Успешность движения в рамках такой системы во многом зависима от перехода новых фундаментальных знаний к их практическому использованию, созданию технологий, продуктов и услуг, их выводу на рынок и, наконец, к проектированию и реализации научных и научно-технических проектов действительно полного цикла.

Указ Президента Российской Федерации от 01.12.2016 г. № 642 утверждает Стратегию научно-технологического развития Российской Федерации (далее - Стратегия). Стратегия определяет собой наиболее чувствительные для научно-технологического развития страны стратегические ориентиры, вызовы и приоритеты.

Указ Президента Российской Федерации от 07.05.2018 г. № 204 (получивший неформальное наименование «майского указа»по аналогии с «майскими указами» 2012 г. (№ 596 - № 606)) определяет национальные цели развития Российской Федерации на период до 2024 г. и перечень национальных проектов (программ), реализация которых способствует достижению национальных целей, в числе которых обозначен и национальный проект (программа) «Наука».

Задачу сохранения интеллектуального потенциала страны, его эффективного использования в целом, и вовлечения результатов научно-технической деятельности (далее - РНТД) в производство продукции в частности, нельзя назвать новой. Еще в 1998 г. Президент Российской Федерации Б.Н. Ельцин в Указе от 22.07.1998 г. № 863 [3] определил приоритетные направления при осуществлении государственной политики по вовлечению в хозяйственный оборот результатов научно-технической деятельности и объектов интеллектуальной собственности в сфере науки и технологий.

Знакомство с названными указами показывает более углубленное и достаточно точное понимание высшим руководством страны проблем, стоящих сегодня перед российским сектором исследований и разработок. На это указывают прямое признание исчерпания возможностей экономического роста России, основанного на экстенсивной эксплуатации сырьевых ресурсов, и упомянутая важность сжатия инновационного цикла в качестве внутреннего фактора изменений в организации научной, научно-технической и инновационной деятельности, следующего за глобальными изменениями.

По мнению авторов, основные смыслы Стратегии и «майского указа» сводятся к трем базовым ценностям: люди; конкурентоспособность; возможность применения новых знаний для создания инновационной, прорывной продукции (товаров, работ, услуг). Справедливость выделения таких базовых ценностей подтверждается и словами главы государства, произнесенными в послании Президента Российской Федерации Федеральному Собранию от 01.03.2018 г. [4], в котором глава государства выделил три указанные составляющие.

Изучение соответствующих документов и выступлений указывают на важность и неотвратимость преобразования научно-технической области, замкнутой на себя, в область, обеспечивающую появление конкурентоспособной реальной продукции (товаров, работ, услуг). Несмотря на все усилия, предпринятые Президентом Российской Федерации, сектору исследований, разработок и инноваций для воплощения таких усилий в жизнь предстоит испытать глобальную трансформацию не столько самого сектора, способов отбора и финансирования научных, научно-технических и инновационных проектов, сколько институтов и принципов государственного управления, в которых такой сектор находится.

Бесспорно, что наиболее ценными и оборотоспособными результатами научных и научно-технических проектов являются результаты интеллектуальной деятельности и интеллектуальные права на них. Научная и научно-техническая информация в Российской Федерации не оборотоспособна, на что указывают изменения, внесенные Федеральным законом от 18.12.2006 г. № 231-Ф3 [5] в статью 128 Гражданского кодекса Российской Федерации (изменения исключили информацию из видов объектов гражданских прав).

И пока эксперты тематической рабочей группы «Интеллектуальная собственность» Центра 
компетенции по нормативному регулированию цифровой экономики, возглавляемого Фондом «Сколково», не преодолели барьера закрепления информации в качестве объекта гражданских прав, фокус текста настоящей статьи будет обращен только к интеллектуальной собственности в ее понимании Гражданским кодексом Российской Федерации.

Авторы в предыдущей публикации уже называли некоторые проблемы государственной политики в области выявления, закрепления и инвентаризации прав на результаты интеллектуальной деятельности, обладающих высоким потенциалом индустриального использования [6]. Нерешенные проблемы порождают риски превращения научных знаний в реальные инновации и не позволют использовать возможности технологической революции для будущего страны. При этом, сам глава государства указывает [4], что использование колоссальных возможностей технологической революции станет для страны решающим в ближайшие годы для будущего страны.

Целью настоящего исследования является выявление причин, порождающих риски реализации амбициозных планов научно-технологического развития экономики, источником которых стало недостаточное урегулирование правил создания интеллектуальной собственности и отсутствие единой методологии управления правами Российской Федерации на результаты интеллектуальной деятельности, созданными с использованием бюджетных средств.

\section{Неопределенность правовой природы соглашения о предоставлении субсидии для бюджетного финансирова- ния исследований}

В 2013-2014 гг. в России укрепилась практика финансирования государством выполнения научно-исследовательских, опытно-конструкторских и технологических работ на основании соглашений о предоставлении субсидии. Так, например, именно соглашения о предоставлении субсидии являются основным инструментом финансирования научных и научно-технических проектов, реализуемых в рамках федеральной целевой программы «Исследования и разработки по приоритетным направлениям развития научно-технологического комплекса России на 2014-2020 годы», утвержденной Постановлением Правительства Российской Федерации от 21.05.2013 г. № 426 [7], являющейся одним из основных механизмов формирования конкурентоспособного и эффективно функционирующего сектора прикладных научных исследований и разработок.

В соответствии с разделом VI указанного постановления, финансовое обеспечение мероприятий 1.1-1.4, 2.1, 2.2, а именно в рамках таких мероприятий предусмотрено проведение исследований, осуществляется путем предоставления из федерального бюджета субсидий в соответствии со статьями 78 и 78.1 Бюджетного кодекса Российской Федерации [8].

Таким образом, только в рамках указанной программы, 64\% общего объема финансирования $(160941,772$ млн. руб. - средств федерального бюджета; в редакции постановления Правительства Российской Федерации от 25.09.2017 г. № 1156 [9]) направляются на прикладные научные исследования и экспериментальные разработки гражданского назначения на основании соглашений о предоставлении субсидий.

В связи с выделением значительных средств из федерального бюджета на выполнение научно-исследовательских, опытно-конструкторских или технологических работ с использованием конструкции соглашения о предоставлении субсидии, возникает обоснованный вопрос, могут ли такие договоры быть надлежащей основой для оформления отношений, связанных с выполнением подобных задач.

Согласно статье 78 Бюджетного кодекса Российской Федерации, субсидии предоставляются на безвозмездной и безвозвратной основе в целях возмещения недополученных доходов и (или) финансового обеспечения (возмещения) затрат в связи с производством (реализацией), выполнением работ, оказанием услуг. Как видно из приведенного определения, субсидия имеет своей целью возмещение затрат такого получателя (несет компенсационный характер), при этом не является возмездной или возвратной (как заем, кредит), является безвозмездной, 
не имеющей какого-либо встречного предоставления (как дарение, пожертвование). В то время как гражданско-правовые договоры относили бы схожие отношения к договору дарения (пожертвования), распространяли бы на возникающие отношения положения законодательства о государственных (муниципальных) закупках и порождали соответствующие налоговые последствия, на практике этого не происходит. Субсидии предоставляются без конкурса, проводимого в соответствии Федеральными законами от 18.07.2011 г. № 223Ф3 [10] и от 05.04.2013 г. № 44-Ф3 [11], на них не распространяются ограничения, предусмотренные такими законами, субсидия не подлежит обложению налогом на добавленную стоимость и т.д.

Кроме того, в отношениях по предоставлению субсидии не возникают и традиционные для гражданско-правовых отношений стороны - кредитор и должник, поскольку полное исполнение обязательств со стороны получателя субсидии имеет целью удовлетворение не интересов «государственного заказчика» (предоставляющего субсидию) как кредитора, а публичных интересов и в пользу таких публичных интересов. При этом, из статей 307-310 Гражданского кодекса Российской Федерации [12] следует, что в силу гражданско-правового обязательства должник обязан совершить в пользу кредитора определенное действие, а кредитор имеет право требовать от должника исполнения его обязанности. В случае с обязательствами по субсидии такого обязательства не прослеживается.

С другой стороны, положения пункта 1 статьи 8 Гражданского кодекса Российской Федерации допускают возникновение гражданских прав и обязанностей на основании соглашений о предоставлении субсидии.

В законодательстве Российской Федерации до сих пор не предусмотрено конкретного ответа относительно квалификации договора (соглашения) о предоставлении субсидии. Не дано такого ответа и в среде цивилистов [13], и в судебной практике.

Например, один из арбитражных судов провел демаркацию субсидии как бюджетных и гражданско-правовых отношений, отнеся возникшие спорные отношения к гражданско-правовым, используя в качестве квалифицирующего признака несоответствие документа-основания выделения средств требованиям, предъявляемым к актам бюджетного законодательства, регулирующим предоставление субсидий, и недоказанность компенсационного характера предоставляемых денежных средств [14].

Таким образом, отнесение существующих нормативных правовых актов, предписывающих и определяющих регламент работы с интеллектуальной собственностью со стороны распорядителей бюджетных средств, находится в зависимости от глубины формального определения в таких актах, собственно, договоров и соглашений, являющихся основаниями для возникновения интеллектуальной собственности. То есть эффективность их регламентов зависит от того, содержат ли тексты прямое указание на субсидии или какие-либо понятия, поглощающие субсидии. Следовательно, в настоящее время невозможно сделать однозначный и в достаточной степени обоснованный вывод о том, следует ли распространять на отношения, возникшие между получателем субсидии и лицом, предоставляющим такую субсидию, требования актов, касающихся возникновения интеллектуальной собственности и распределения интеллектуальных прав. Рассмотрим возникающую ситуации на более развернутом примере.

Гражданский кодекс Российской Федерации допускает создание результатов интеллектуальной деятельности по заказу и(или) в связи с выполнением работ, однако не требует от государственного (муниципального) заказчика приобретения исключительных прав и не гарантирует ему их приобретения.

В соответствии со статьями 1296-1298, 1371-1373, 1431-1432, 1463-1464 и 1471 Гражданского кодекса Российской Федерации, исключительное право может быть передано на основании договора подряда либо договора на выполнение научно-исследовательских, опытно-конструкторских или технологических работ. В соответствии со статьей 1234 Гражданского кодекса Российской Федерации исключительное 
право может быть передано на основании договора об отчуждении исключительного права (или права на получение патента для объектов, требующих обязательной государственной регистрации).

Договор (соглашение) о предоставлении субсидии не относится ни к числу договоров подрядного типа, ни к договору об отчуждении исключительного права (или права на получение патента). Исчерпывающий перечень оснований для распределения исключительного права, предусмотренный на сегодняшний день в Гражданском кодексе Российской Федерации, не содержит оснований для распределения исключительного права в таком договоре (соглашении) в пользу государственного (муниципального) органа власти, предоставившего субсидию.

Компенсационный характер таких соглашений прямо исключает применение к ним аналогии положений о договорах подрядного типа.

Как отмечалось ранее, наиболее близким по своей природе, регулирующим наиболее сходные гражданско-правовые отношения, является договор дарения (пожертвования). Основным квалифицирующим признаком такого договора является отсутствие встречного представления со стороны одаряемого.

Вместе с тем, наличие такого признака идет вразрез с требованиями нормативно-правовых актов, предписывающих обязательные условия распределения прав на получаемые за счет бюджетных ассигнований федерального бюджета результаты интеллектуальной деятельности, и актов, определяющих положения по контролю и надзору в сфере их правовой охраны и использования. Получаемые в результате выполнения договоров (контрактов), указанных в таких актах, результаты интеллектуальной деятельности требуют от государственного заказчика в ряде случаев приобретения исключительного права на них в пользу Российской Федерации. Именно, встречные обязательства получателя субсидии по передаче исключительного права Российской Федерации исключают возможность отнесения соглашений о предоставлении субсидии даже к договорам дарения (пожертвования).

Описанный казус нормативно-правового регулирования приводит к тому, что соглашения о предоставлении субсидии могут содержать в себе, вероятно, лишь номинальные распределения интеллектуальных прав, не приводящие к каким-либо реальным юридическим последствиям, к переходу исключительного права в пользу Российской Федерации, или, соответственно, приводящие к утрате реального влияния и контроля государства за создаваемой интеллектуальной собственностью.

Поэтому представляется целесообразным:

- либо ограничить распорядителя бюджетных средств в возможностях заключения соглашений о предоставлении субсидии в случаях, когда ожидается получение результатов, исключительное право на которые подлежит закреплению за Российской Федерацией, и в целях исключения разночтений прямо отразить в положениях Бюджетного кодекса Российской Федерации следующую из системного толкования нормативных правовых актов недопустимость распределения интеллектуальных прав на создаваемые результаты интеллектуальной деятельности;

- либо внести изменения в Гражданский кодекс Российской Федерации, расширив перечень допустимых случаев перехода (передачи) интеллектуальных прав в отношениях с участием государственного (муниципального) заказчика.

\section{Отсутствие кодифицированного свода правил и условий создания интеллектуальной собственности и управления правами на нее}

На отношения государственного заказчика и исполнителя или получателя субсидии (если абстрагироваться от неопределенности правовой природы соглашения о предоставлении субсидии и исходить из допустимости того, что к ним применяется регулирование, аналогичное регулированию государственных контрактов), касающиеся создания интеллектуальной собственности, оказывает влияние достаточно большое число разрозненных нормативно-правовых актов. При этом какие-то из них были приняты более 20 лет назад, а некоторые акты практически не содержат в себе регулирующих положений. Рассмотрим основные нормативно-правовые акты подробнее. 
- Постановление Правительства Российской Федерации от 02.09.1999 г. № 982 [15] требует от государственных заказчиков включения в государственные контракты следующих положений:

1) о распределении интеллектуальных прав;

2) об уведомлении исполнителями государственного заказчика обо всех созданных при реализации государственного контракта результатах интеллектуальной деятельности;

3) об условиях использования результатов интеллектуальной деятельности для обеспечения федеральных государственных нужд. Согласно этому положению, такое использование осуществляется, как правило, на основе безвозмездной неисключительной лицензии, предоставляемой государственным заказчиком. Следует отметить, что такое положение вступает в диссонанс с положениями, предусмотренными в статьях 1298, 1373 и 1432 Гражданского кодекса Российской Федерации, которые предусматривают обязанность правообладателя по требованию государственного или муниципального заказчика предоставить указанному им лицу [не самому заказчику] безвозмездную простую (неисключительную) лицензию на использование соответствующего результата интеллектуальной деятельности для государственных или муниципальных нужд.

- Распоряжение Правительства Российской Федерации от 30.11.2001 г. № 1607-р [16] предписывает, каким должен быть выбор государственного заказчика в отдельных условиях, предусматриваемых во исполнение постановления Правительства Российской Федерации от 02.09.1999 г. № 982, при наступлении указанных в нем обстоятельств.

Распоряжение требует от государственных заказчиков обязательного закрепления за государством прав на результаты интеллектуальной деятельности и другие РНТД, которые имеют (совокупно) все следующие характеристики:

- созданы за счет средств федерального бюджета,

- непосредственно связаны с обеспечением обороны и безопасности страны,

- их доведение до стадии промышленного применения берет на себя государство.
При этом, распоряжение правами от имени Российской Федерации возлагается на государственных заказчиков, согласно пункту 3 постановления Правительства Российской Федерации от 02.09.1999 г. № 982. В случае, если обладателем исключительного права становится третье лицо (не государственный заказчик), а такой договор предусматривает последующую передачу прав, государственный заказчик должен предусмотреть ряд дополнительных обязательств правообладателя и исполнителя, связанных с использованием и применением полученных результатов, а также последствия их неиспользования.

Постановление Правительства Российской Федерации от 22.04.2009 г. № 342 [17] пришло на смену действовавшему ранее постановлению Правительства Российской Федерации от 17.11.2005 г. № 685 [18], сохранив действие последнего в силе, несмотря на то, что последняя его редакция имеет скорее технический характер.

Указанное постановление дополняет установленные распоряжением Правительства Российской Федерации от 30.11.2001 г. № 1607-р варианты обязательного выбора государственным заказчиком условий государственных контрактов на выполнение НИОКТР (табл. I, табл. 2).

Этап создания РИД и их приемки в некоторой степени раскрыт в пункте 3 Правил осуществления государственными заказчиками управления правами Российской Федерации на результаты интеллектуальной деятельности гражданского, военного, специального и двойного назначения, утвержденных постановлением Правительства РФ от 22.03.2012 г. № 233 [19] (далее - Правила управления правами РФ на РИД), и предусматривает в соответствии с указанными правилами:

1) осуществление мероприятий по оформлению прав Российской Федерации на результаты интеллектуальной деятельности, используемые и (или) созданные при выполнении государственных контрактов;

2) государственный учет результатов НИОКТР гражданского, военного, специального и двойного назначения; 


\section{Условия распределения исключительного права в государственных контрактах на выполнение НИОКТР}

\begin{tabular}{|c|c|c|}
\hline Российской Федерацией, если: & $\begin{array}{l}\text { совместно исполнителем } \\
\text { и Российской Федерацией, } \\
\text { если: }\end{array}$ & исполнителем: \\
\hline РНТД изъяты из оборота; & \multirow{5}{*}{$\begin{array}{l}\text { результаты непосредственно } \\
\text { связаны с обеспечением } \\
\text { обороны и безопасности } \\
\text { государства } \\
\text { (по решению } \\
\text { государственного } \\
\text { заказчика) }\end{array}$} & \multirow[t]{5}{*}{ в иных случаях } \\
\hline $\begin{array}{l}\text { Российская Федерация приняла на себя осуществление финан- } \\
\text { сирования работ по доведению РНТД до стадии практического } \\
\text { применения, завершающейся этапом постановки продукции на } \\
\text { производство, включающим подготовку производства, изготовле- } \\
\text { ние установочной серии и квалификационные испытания; }\end{array}$ & & \\
\hline $\begin{array}{l}\text { исполнитель не обеспечил до истечения } 6 \text { месяцев после окон- } \\
\text { чания НИОКТР совершение всех действий, необходимых для } \\
\text { признания за ним или приобретения им исключительных прав } \\
\text { на РНТД; }\end{array}$ & & \\
\hline $\begin{array}{l}\text { РНТД созданы в ходе НИОКР, выполняемых во исполнение } \\
\text { международных обязательств Российской Федерации; }\end{array}$ & & \\
\hline $\begin{array}{l}\text { результаты непосредственно связаны с обеспечением обороны } \\
\text { и безопасности государства } \\
\text { (государственный заказчик уполномочен изменить это правило - } \\
\text { см. следующий столбец) }\end{array}$ & & \\
\hline
\end{tabular}

Таблица 2

\section{Условия распределения расходов по обеспечению правовой охраны в государственных контрактах на выполнение НИОКТР}

\begin{tabular}{|c|c|c|}
\hline \multicolumn{3}{|c|}{$\begin{array}{c}\text { Расходы по обеспечению правовой охраны результатов интеллектуальной деятельности } \\
\text { при закреплении прав на них осуществляются за счет }\end{array}$} \\
\hline $\begin{array}{c}\text { выделяемых государственным заказчикам средств } \\
\text { федерального бюджета, если: }\end{array}$ & $\begin{array}{c}\text { средств исполнителя } \\
\text { и государственного заказчика } \\
\text { в равных долях, если: }\end{array}$ & $\begin{array}{c}\text { средств } \\
\text { исполнителя, } \\
\text { если: }\end{array}$ \\
\hline права закреплены за Российской Федерацией & $\begin{array}{l}\text { права закреплены совместно } \\
\text { за исполнителем и Российской } \\
\text { Федерацией }\end{array}$ & $\begin{array}{l}\text { права закреплены } \\
\text { за исполнителем }\end{array}$ \\
\hline
\end{tabular}

3) организацию работ по оценке стоимости и принятие на бухгалтерский учет прав на результаты интеллектуальной деятельности.

Несмотря на предусмотренное достаточно интенсивное взаимодействие государственного заказчика с исполнителем, ни в самом тексте Правил управления правами РФ на РИД, ни в утверждающем их постановлении Правительства Российской Федерации от 22.03.2012 г. № 233, ни в Указе Президента РФ от 24.05.2011 г. № 673 [20], в соответствии с которым принято указанное постановление, не содержится достаточного разграничения траекторий взаимодействия заказчика и исполнителя по поводу предоставления правовой охраны в зависимости от того, кто становится правообладателем соответствующих результатов интеллектуальной деятельности, создаваемых на основании или в связи с государственными контрактами.

Кроме того, существенный объем вопросов возникает и к формулировке рассматриваемой меры, и к ее элементам. Так, в частности:

- в тексте Правил управления правами РФ на РИД не приводятся способы (порядок, условия) оформления прав на результаты интеллектуальной деятельности, использованные при выполнении государственных контрактов, но не созданные в рамках таких контрактов; 
- не раскрыто предназначение уведомлений об использованных результатах интеллектуальной деятельности;

- не предложены и не определены принципы или условия принятия решений о правовой охране полученных результатов интеллектуальной деятельности;

- при наличии требования об уведомлении исполнителем о получении результата интеллектуальной деятельности, способного к правовой охране, не определен порядок извещения заказчика о получении результата интеллектуальной деятельности, уже имеющего правовую охрану (программ для ЭВМ, баз данных и ТИМС);

- не определено, является ли обязательным для исполнителя проведение патентных исследований в случаях, когда такие работы не предусмотрены государственным контрактом;

- решения государственного заказчика о способе правовой охраны результатов интеллектуальной деятельности не увязаны с расходами исполнителя, возникающими в связи с обеспечением такой правовой охраны, не определено, включает ли финансирование по государственному контракту выделяемые государственным заказчиком средства федерального бюджета на обеспечение правовой охраны результатов интеллектуальной деятельности при закреплении прав на них за Российской Федерацией в соответствии с постановлением Правительства РФ от 22.04.2009 г. № 342, в особенности, в зарубежных странах.

Несмотря на отмеченные недостатки, применение указанных мер, тем не менее, позволяет государственным заказчикам построить эффективную работу с результатами интеллектуальной деятельности, устранив отмеченные и иные недостатки в собственных (ведомственных) нормативных актах.

В соответствии с пунктом 6 Правил управления правами РФ на РИД, государственные заказчики обязаны вести государственный учет результатов НИОКТР гражданского, военного, специального и двойного назначения, права на которые принадлежат Российской Федерации. Представляется, что такая словесная конструкция используется в тексте указанных правил в целях смыслового усиления оборота, относимого к непосредственной обязанности государственного заказчика, поскольку и в существовавшем за 10 лет до появления указанных правил постановлении Правительства Российской Федерации от 26.02.2002 г. № 131 [21], касающемся результатов НИОКТР военного, специального и двойного назначения, и в вышедшем годом позже их утверждения постановлении Правительства Российской Федерации от 12.04.2013 г. № 327 [22], касающемся результатов НИОКТР гражданского назначения, объем результатов, подлежащих государственному учету, не ограничивается теми, права на которые принадлежат Российской Федерации.

Из последних перечисленных актов следует, что все результаты интеллектуальной деятельности, полученные с использованием средств бюджета, подлежат отражению и государственному учету, а информация о них накапливается и предоставляется безвозмездно. И именно в целях информационного обеспечения научной, научно-технической и инновационной деятельности, информационного обеспечения деятельности исполнителей работ, заинтересованных федеральных органов исполнительной власти и Фонда перспективных исследований, а также в целях использования результатов интеллектуальной деятельности и прав на них в гражданско-правовом обороте указанными постановлениями были созданы системы государственного учета.

Несмотря на то, что такая государственная регистрация по смыслу Гражданского кодекса Российской Федерации и в соответствии с закономерным письмом Минобрнауки России от 09.06.2016 г. № 14-930 [23] не порождает каких-либо интеллектуальных прав ни у государственного (муниципального) заказчика, ни у исполнителя, равно как и не расценивается судами как влияющая на правовую охрану, это не является основанием для неисполнения требований пункта 3 Правил управления правами РФ на РИД, касающихся государственного учета результатов НИОКТР гражданского, военного, специального и двойного назначения.

Значимость корректного и полного государственного учета результатов НИОКТР 
и сведений о них, помимо очевидных, имеет и стратегические причины. В соответствии с пунктом 4 Правил мониторинга реализации Стратегии, утвержденных постановлением Правительства Российской Федерации от 07.04.2018 г. № 421 [24], мониторинг осуществляется посредством анализа данных, сведений или информации государственных информационных систем и иных источников, к числу которых отнесена и единая государственная информационная система учета научно-исследовательских, опытно-конструкторских и технологических работ гражданского назначения (ЕГИСУ НИОКТР), созданная постановлением Правительства Российской Федерации от 12.04.2013 г. № 327.

Ввиду того, что Стратегия является документом стратегического планирования, определяющим стратегические цели и основные задачи, направления и приоритеты государственной политики, ориентированные на устойчивое, динамичное и сбалансированное научно-технологическое развитие Российской Федерации на долгосрочный период, использование для целей мониторинга неполных или недостоверных данных ставит под угрозу эффективность ее реализации.

- Положение об инвентаризации прав на результаты научно-технической деятельности, утвержденное постановлением Правительства Российской Федерации от 14.01.2002 г. № 7 [25], определяет порядок проведения инвентаризации прав на РНТД, полученные при выполнении НИОКТР, полностью или частично финансируемых за счет средств федерального бюджета.

Согласно пункту 2 Положения об инвентаризации прав на результаты научно-технической деятельности, инвентаризация включает в себя следующие мероприятия:

- осуществление научно-технического, правового и экономического анализа РНТД, информация о которых зафиксирована на материальных (информационных) носителях, в том числе содержащихся в отчетной научно-технической, проектной, конструкторской, технологической и другой документации, с целью выявления РНТД, являющихся объектами исключительных прав, потенциально охраноспособных РНТД и РНТД, которые не могут являться объектами исключительных прав (далее - выявленные РНТД);

- идентификация субъектов прав на указанные выявленные РНТД;

- разработка рекомендаций по получению правовой охраны на выявленные РНТД в качестве объектов исключительных прав или введению в отношении информации о них режима коммерческой тайны, а также рекомендаций по использованию выявленных РНТД в гражданском обороте.

При проведении инвентаризации рабочая инвентаризационная комиссия по каждому выявленному РНТД:

- определяет в соответствии с законодательством Российской Федерации и (или) договором на выполнение работ, в ходе которых получен РНТД, потенциального правообладателя или правообладателя;

- вырабатывает рекомендации по осуществлению юридически значимых действий по правовой охране выявленных РНТД в качестве объектов исключительных прав или по введению в отношении информации о выявленном РНТД режима коммерческой тайны (в отношении РНТД, которые не могут являться объектами исключительных прав, а также потенциально охраноспособных).

В состав комиссий, создаваемых государственными заказчиками для приемки обязательств по государственным контрактам и соглашениям о предоставлении субсидии, которые, на практике, повсеместно формируются в структурах государственных заказчиков, рекомендуется включать также и членов рабочей инвентаризационной комиссии, создаваемой руководителем организации, с целью одновременного при приемке обязательств проведения инвентаризации (выявления прав на РНТД с целью их последующего учета и правомерного использования в гражданском обороте).

Поскольку естественной частью работ по инвентаризации является проверка исполнения объектом условий для принятия его к бухгалтерскому учету, на данной стадии подлежит также определить применимый акт, касающийся учета исключительных прав в качестве объектов 
нематериальных активов. Для государственных заказчиков таковым является приказ Минфина России от 01.12.2010 г. № 157н [26] (для некоторых иных лиц - приказы Минфина России от 27.12.2007 г. № 153н [27] или от 28.12.2015 г. № 217н [28] (приложение 25)). Соответственно, в состав комиссий, создаваемых государственными заказчиками для приемки обязательств по государственным контрактам и соглашениям о предоставлении субсидии, могут быть включены также и члены комиссии по поступлению и выбытию активов, что позволит существенно сократить период со дня возникновения соответствующего права до дня надлежащего отражения операций с ним в бухгалтерском учете.

Как отмечалось ранее, Гражданский кодекс Российской Федерации не предусматривает случаев, когда исключительное право принадлежит государственному заказчику. Исключительное право на результаты интеллектуальной деятельности, полученные в рамках или в связи с выполнением государственного (муниципального) контракта, может быть распределено в пользу Российской Федерации, ее субъекта или муниципального образования (либо совместно с исполнителем). Государственный (муниципальный) заказчик в таком случае лишь осуществляет распоряжение правами от имени, соответственно, Российской Федерации, ее субъекта или муниципального образования. Ввиду такого казуса, в целях обеспечения подпункта «в» пункта 3 Правил управления правами РФ на РИД и исключения нарушений, которые могут быть определены контрольно-надзорными органами, например, Счетной палатой Российской Федерации ${ }^{3}$, государственному заказчику следует исходить из допущения принадлежности ему исключительного права.

3 Счетная палата Российской Федерации осуществляет внешний государственный аудит (контроль) в отношении, в том числе, ФОИВ. В рамках такого аудита (контроля) Счетной палатой Российской Федерации неоднократно отмечались нарушения бюджетного законодательства, заключающиеся в отсутствии учета HМА в ФОИВ, в том числе, в отношении Федерального агентства по делам молодежи (http://www.ach. gov.ru/activities/control/elimination-of-violations/26625), Министерства культуры Российской Федерации (http:// www.ach.gov.ru/activities/control/30508), Федерального агентства научных организаций (http://www.ach.gov. ru/activities/control/32131).
Возвращаясь к распоряжению Правительства РФ от 30.11.2001г. № 1607-р, следует отметить, что, помимо прочего, распоряжение прямо обязывает государственных заказчиков использовать рычаги экономической и хозяйственной политики для эффективного использования прав на РИД, способствовать капитализации затрат на НИОКТР в составе затрат на производство продукции.

Федеральные органы исполнительной власти (далее - ФОИВ) обязаны эффективно осуществлять в пределах своей компетенции распоряжение закрепленными за государством правами на результаты интеллектуальной деятельности в целях их доведения до стадии промышленного применения и реализации готовой продукции с привлечением при необходимости организаций-разработчиков.

Как указано ранее, в случаях, когда государственные контракты или иные договоры предусматривают финансирование создания РИД за счет средств федерального бюджета и одновременно последующую передачу прав на результаты интеллектуальной деятельности, указанное распоряжение предписывает предусматривать в таких контрактах и договорах для стороны, получающей исключительное право, также следующие условия:

1) конкретные обязательства по обеспечению доведения разработок до стадии промышленного применения и реализации готовой продукции;

2) порядок материального поощрения организаций-исполнителей,

3) порядок выплаты вознаграждения авторам,

4) конкретные обязательства стороны, реализующей в производственной практике результаты интеллектуальной деятельности, и санкции за невыполнение этих обязательств.

Вне зависимости от того, какие именно полномочия получает контрагент-приобретатель интеллектуальных прав на результаты интеллектуальной деятельности, созданные за счет средств федерального бюджета, - обладателя исключительного права или лица, использующего их на основании лицензии, в договорах, заключаемых с таким лицом, следует предусматривать возможность изъятия государством прав 
на использование соответствующих результатов [исключительных прав], если организация-обладатель прав в течение установленного срока не предприняла эффективных мер для их практического использования и введения в хозяйственный оборот или если лицензиат нарушает условие об использовании преимущественно в России объектов интеллектуальной собственности или созданного с их использованием продукта.

Право ФОИВ распоряжаться от имени Российской Федерации правами на РНТД в соответствии с порядком, определяемом Правительством Российской Федерации, предусмотренное постановлением Правительства РФ от 02.09.1999 г. № 982, в распоряжении Правительства РФ от 30.11.2001 г. № 1607-р, было трансформировано уже в обязанность. И в целях определения такого порядка, несмотря на все свои недостатки, именно Правила управления правами РФ на РИД внесли существенный и беспрецедентный, как минимум, с 1999 г. вклад в активизацию использования и управления правами на результаты интеллектуальной деятельности, правообладателем которых выступает Российская Федерация.

Распоряжение государственными заказчиками правами Российской Федерации на результаты интеллектуальной деятельности, согласно пункту 7 Правил управления правами РФ на РИД, осуществляется путем совершения одного из следующих действий:

1) отчуждение от имени Российской Федерации исключительного права на результаты интеллектуальной деятельности;

2) предоставление права использования результатов интеллектуальной деятельности на основе лицензионного договора;

3) внесение исключительного права на результаты интеллектуальной деятельности или права использования результата интеллектуальной деятельности в уставный капитал государственной корпорации (передача в качестве имущественного взноса Российской Федерации), уставный фонд федерального государственного унитарного предприятия, а также в уставный (складочный) капитал хозяйственного товарищества или общества или складочный капитал хозяйственного партнерства либо передача права на результат интеллектуальной деятельности в залог в случаях, предусмотренных законодательством Российской Федерации;

4) принятие от имени Российской Федерации решения о досрочном прекращении действия патента на результат интеллектуальной деятельности.

Определенные Правительством Российской Федерации способы распоряжения интеллектуальными правами покрывают абсолютное большинство наиболее распространенных способов, однако, не включают в себя особое, уникальное право государственного заказчика, принадлежащее ему в случаях, когда исключительное право закрепляется за исполнителем - право требовать предоставления права использования третьему лицу.

В соответствии с пунктом 7(1) Правил управления правами РФ на РИД, в отношении тех результатов интеллектуальной деятельности, по которым государственными заказчиками не принято решений о распоряжении правами на них одним из вышеуказанных способов, государственные заказчики обязаны не реже 1 раза в год осуществлять рассмотрение вопроса о целесообразности сохранения исключительных прав Российской Федерации на такие результаты интеллектуальной деятельности.

Анализ официальных сайтов отдельных ФОИВ (по состоянию на 12.04.2018г.) показывает, что, несмотря на приложенные усилия и прямые поручения Правительства Российской Федерации, уже приняты решения о распоряжении исключительным правом на все результаты интеллектуальной деятельности, «операторами» прав на которые они являются, либо информация об указанных результатах интеллектуальной деятельности составляет государственную тайну, или они не спешат с полным исполнением постановления Правительства Российской Федерации, поскольку перечни размещены лишь на единичных сайтах из числа проанализированных (табл. 3).

Примечательно, что все принятые порядки учета РИД в значительной степени сходны друг с другом, имеют незначительные редакционные отклонения, а порядки Минздрава 
Таблица 3

Данные официальных сайтов министерств и ведомств о распоряжении исключительным правом на результаты интеллектуальной деятельности
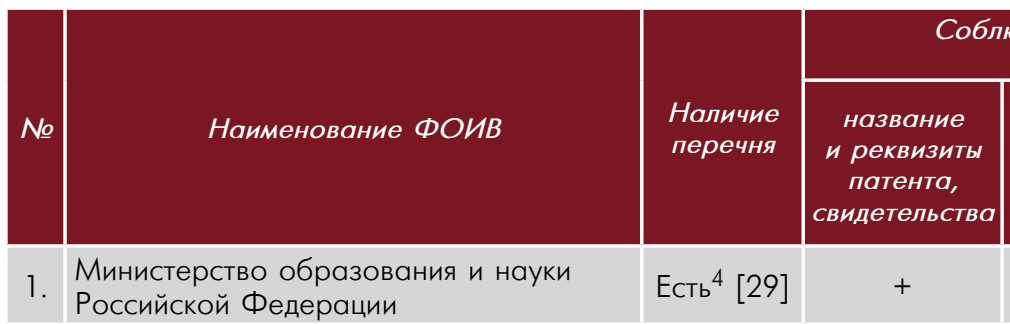

Соблюдение требований к информации, включаемой в перечень

1. Министерство образования и науки Российской Федерации

2. Министерство внутренних дел

Российской Федерации (www.mvd.ru)

3. Министерство иностранных дел

3. Российской Федерации (www.mid.ru)

4. Министерство юстиции Российской Федерации (www.minjust.ru) Министерство здравоохранения

5. Российской Федерации (www.rosminzdrav.ru)

6. Министерство культуры Российской Федерации (www.mkrf.ru) Министерство связи и массовых

7. коммуникаций Российской Федерации (www.minsvyaz.ru)

8. Министерство сельского хозяйства

8. Российской Федерации (www.mcx.ru)

9. Федеральное архивное агентство (http://archives.ru)

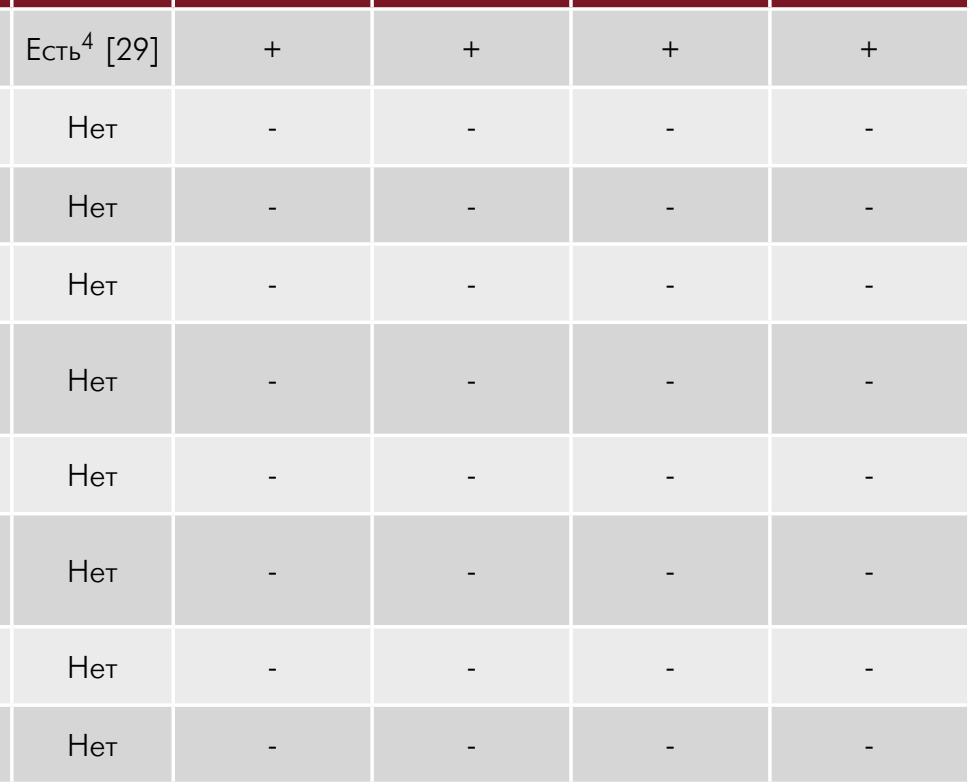

России, Минкомсвязи России и Минсельхоза России в значительной (большей) степени повторяют порядок Минобрнауки России, приняты в 2016 г. по мере территориальной удаленности указанных ФОИВ от Министерства образования и науки Российской Федерации.

Таким образом, ФОИВ или другие распорядители бюджетных средств, даже имея желание построения эффективно работающей системы управления интеллектуальными правами на результаты интеллектуальной деятельности, созданные при их финансировании, столкнутся с потребностью набора высококвалифицированных специалистов-юристов, обладающих знаниями ретроспективы развития права интеллектуальной собственности, для принятия взвешенных и обоснованных решений по вопросам интеллектуальной собственности, что представляется затруднительным в условиях текущих размеров оплаты труда государственных служащих и нагрузки на них.

На деле, принятие решений о распределении исключительного права между государственным заказчиком и исполнителем (подрядчиком) фактически возложено на должностное лицо, формирующее заказ на выполнение работ. Помимо того, что для принятия решения такое должностное лицо должно обладать необходимой квалификацией, отклонение от предписанных траекторий распределения прав грозит ему нарушением требований, установленных Правительством Российской Федерации. И, в условиях угрозы возникновения ответственности за нарушение каких-либо требований, представляется, что любой государственный служащий предпочтет сохранить их за Российской Федерацией просто потому, что при

4 Перечень представлен в PDF версии приложения к распоряжению Минобрнауки России от 24.02.2016 г. № P-25. 
этом фактор риска ниже, даже несмотря на последствия, порождаемые таким решением для последующей судьбы таких результатов и повышению шанса их стагнации.

В ряде случаев такое решение может быть предопределено на уровне Правительства Российской Федерации по родовому признаку. Так, например, мероприятиями 1.2, 1.3, 1.4, 2.1 и 2.2 упомянутой ранее федеральной целевой программы «Исследования и разработки по приоритетным направлениям развития научно-технологического комплекса России на 2014-2020 годы» (далее - ФЦП ИиР) предусмотрено проведение прикладных научных исследований и исследований в рамках международного многостороннего и двустороннего сотрудничества, в том числе с государствами-членами Европейского союза.

Цели и иные отдельные релевантные для целей настоящей статьи условия отбора проектов в рамках мероприятий 1.2-1.4 ФЦП ИиР (извлечения из ФЦП ИиР) приведены в табл. 4.

Из представленного описания (строки 3 и 4) следует, что результаты проекта имеют общее свойство - высокую степень готовности для постановки продукции на производство. Причем, с повышением порядкового номера мероприятия степень их готовности также повышается.

Это свойство результатов может приводить к применению к таким результатам требований, определенных постановлением Правительства Российской Федерации от 22.04.2009 г. № 342, согласно которым закрепление исключительного права на полученные результаты должно осуществляться в пользу Российской Федерации.

Вместе с тем, наличие конкретного потребителя таких результатов, который берет на себя обязательства по коммерциализации результатов впоследствии (строка 3), наряду с закреплением прав на них за Российской Федерации, существенно затрудняет передачу или предоставление прав на такие результаты для последующей коммерциализации по ряду причин. Во-первых, длительность проведения бюрократических процедур государственного заказчика по согласованию сделки, способствующей коммерциализации, способна нивелировать экономическое преимущество, получаемое от результатов. Во-вторых, государственный заказчик в своей деятельности должен подчиняться Правилам управления правами РФ на РИД. Это значит, что передача и предоставление прав третьему лицу должны осуществляться при обязательном осуществлении процедур, предписанных такими правилами, что подтверждается судебной практикой, например, по делу $\mathrm{AO}$ «Краснодарский станкостроительный завод Седин» против Министерства промышленности и торговли Российской Федерации [30].

Ввиду обозначенных причин, обоснованным представляется распределять права на результаты, создаваемые при выполнении проектов в рамках мероприятий 1.2-1.4 ФЦП ИиР за исполнителем (получателем субсидии). Однако, это решение создает угрозу ненадлежащего исполнения требований постановления Правительства Российской Федерации от 22.04.2009 г. № 342.

Аналогичные неопределенности справедливы и в отношении результатов проектов, создаваемых рамках мероприятий 2.1 и 2.2 ФЦП ИиР. Основанием для проведения исследований, выполняемых в рамках 2.1 и 2.2 ФЦП ИиР, являются межведомственные и межправительственные соглашения. Поскольку такие соглашения могут и, вероятнее всего, определяют международные обязательства Российской Федерации, согласно постановлению Правительства Российской Федерации от 22.04.2009 г. № 342, права на такие результаты также подлежат иррациональному закреплению за Российской Федерацией.

Ввиду того, что требования, определяющие распределение исключительного права на результаты интеллектуальной деятельности, полученные при использовании бюджетных средств, были утверждены Правительством Российской Федерации, в документах, касающихся исполнения ФЦП ИиР, также утверждаемых Правительством Российской Федерации, целесообразно прямо определить условия распределения прав на результаты, получаемые при реализации ФЦП ИиР. Это лишит риска недостаточно обоснованного распределения исключительного права между государственным заказчиком и исполнителем (получателем субсидии). 


\section{Таблица 4}

\section{Извлечения из Федеральной целевой программы «Исследования и разработки по приоритетным направлениям развития научно-технологического комплекса России на 2014-2020 годы» по мероприятиям 1.2-1.4}

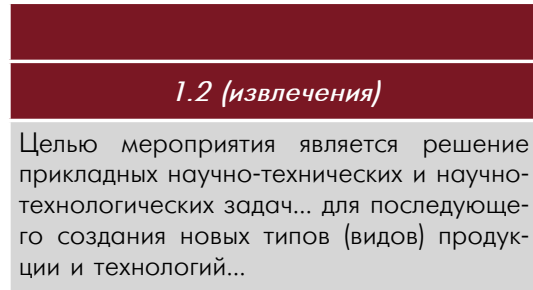
ции и технологий.

Финансирование прикладных научных исследований осуществляется на условиях... привлечения к дальнейшему практическому использованию (коммерциализации) их результатов конкретных потребителей результатов работ.

Поддерживаются проекты, имеющие конкретного потребителя результата, который принимает на себя обязательство... обеспечить дальнейшее практическое использование результатов работ (коммерциализацию).

Результатами выполнения проектов мероприятия являются:

разработанные новые технические (технологические) решения и результаты интеллектуальной деятельности, полученные при исследовании свойств и (или) особенностей функционирования и (или) применения материалов (устройств, процессов) с использованием созданных макетов, моделей, экспериментальных образцов...

\section{Мероприятия ФЦП ИиР}

1.3 (извлечения)

Целью мероприятия является обеспечение инновационного развития отраслей экономики посредством создания востребованных научно-технических решений... нацеленных на создание продуктов и услуг для новых рынков..

Финансирование прикладных научных исследований и экспериментальных разработок осуществляется на условиях... привлечения к дальнейшему практическому использованию (коммерциализации) их результатов конкретных потребителей результатов работ.

Поддерживаются проекты, имеющие конкретного потребителя результата, который принимает на себя обязательство.. обеспечить дальнейшее практическое использование результатов работ (коммерциализацию).

Результатами выполнения проектов мероприятия являются:

разработанные новые технические (технологические) решения и результаты интеллектуальной деятельности, полученные при исследовании свойств и (или) особенностей функционирования и (или) применения материалов (устройств, процессов) с использованием созданных макетов, моделей, экспериментальных образцов, и (или) опытных образцов... направленные на решение практических задач по созданию продуктов и услуг для новых рынков...;

комплект технической документации, отражающий новые технические (технологические) решения, подтвержденные результатами исследовательских и других испытаний моделей, макетов, натурных составных частей изделий и экспериментальных образцов продукции в целом в условиях, как правило, имитирующих реальные условия эксплуатации (потребления), и предназначенный для использования в последующем промышленном внедрении.

\section{4 (извлечения)}

Целью мероприятия является обеспечение решения важнейших научно-технических (научно-технологических) проблем (задач) в интересах государства, общества, регионов, отраслей, имеющих определяющее значение для инновационного развития экономики, решение которых обычными инструментами нецелесообразно или невозможно

Финансирование прикладных научных исследований и экспериментальных разработок осуществляется на условиях.. привлечения к дальнейшему практическому использованию (коммерциализации) их результатов заинтересованных профильных организаций...

С заинтересованными ФОИВ, органами государственной власти субъектов Российской Федерации и организациями заключается соглашение о дальнейшем использовании результатов работы в целях их последующей коммерциализации.

Финансируемые в рамках мероприятия прикладные научные исследования и экспериментальные разработки должны быть направлены преимущественно на применение полученных научно-технических результатов и экспериментальную проработку проектно-конструкторских (конструктивно-технологических) решений, включая подтверждение их практической осуществимости..

Результатами выполнения проектов мероприятия являются:

разработанные новые технические (технологические) решения и результаты интеллектуальной деятельности, полученные при исследовании свойств и (или) особенностей функционирования и (или) применения материалов (устройств, процессов) с использованием созданных макетов, моделей, экспериментальных образцов и (или) опытных образцов, отраженные в научно-методической, нормативно-технической, эскизной технической (конструкторской, программной, технологической) документации и направленные на решение практических задач;

комплект технической документации, отражающий новые технические (технологические) решения, подтвержденные результатами исследовательских и других испытаний моделей, макетов, натурных составных частей изделий и экспериментальных образцов продукции в целом в условиях, как правило, имитирующих реальные условия эксплуатации (потребления), и предназначенный для использования в последующем промышленном внедрении. 
Указанное обнажает еще одну проблему действующей распределенной системы нормативных правовых актов - длительное отсутствие аудита, оценки актуальности и обоснованности положений таких актов. Представляется обоснованным, что, как минимум, положения, определяющие отдельные условия распределения исключительного права на результаты интеллектуальной деятельности в пользу Российской Федерации являются устаревшими.

Кроме того, очевидно, что текущее нормативно-правовое регулирование, несмотря на его минимальную достаточность, нельзя назвать всеобъемлющем, не имеющем пробелов. Так, например, оно не предусматривает выполнения каких-либо функций мониторинга результатов интеллектуальной деятельности (не только тех, правообладателем которых является Российская Федерация) и их внедрения после выполнения всех формальных процедур, связанных с финансированием проекта, не называет последствий утраты результатами правовой охраны, принципов действий и действий государственного заказчика в связи с этим. Как указывалось выше, оно не дает распорядителям бюджетных средств и ориентиров по осуществлению уникальных прав требования предоставления безвозмездных лицензий для государственных нужд.

По причинам проиллюстрированного отставания нормативного регулирования за объективным развитием общества, нормативные правовые акты не предусматривают и возрастания роли представителей реального сектора экономики, участвующих в научных, научно-технических, инновационных и комплексных проектах как денежными средствами, так и посредством применения их результатов.

Представляется, что и Правила управления правами РФ на РИД, которые были призваны стимулировать активное участие государственных заказчиков в процессах вовлечения в хозяйственный оборот результатов научно-технической деятельности, интеллектуальной собственности в сфере науки и технологий и прав на них, в случае, если на сегодняшний день они действительно стали дополнительной процессуальной процедурой, затрудняющей доступ заинтересованных потребителей к существующей интеллектуальной собственности, также подлежат уточнению.

\section{Стохастическая работа с интеллектуальной собственностью}

Ввиду значительного государственного участия в финансировании НИОКТР сохраняется потребность в единой, понятной и прозрачной методологии и алгоритмизации управления правами Российской Федерации на результаты интеллектуальной деятельности, создаваемые с использованием бюджетных средств. Их отсутствие приводит к различающимся подходам государственных заказчиков при принятии обязательных и необходимых мер, связанных с интеллектуальной собственностью. При этом возрастающая роль государства в инициации, разработке и реализации проектов полного жизненного цикла, включающего в себя все этапы инновационного цикла, вызывает необходимость придания государственным заказчикам не только полноценных прав распоряжения результатами, но и обязанностей по управлению правами на все результаты интеллектуальной деятельности, в том числе принадлежащие исполнителям или третьим лицам.

Как можно убедиться из приведенного анализа, в настоящее время такие права и обязанности не находятся в гармонии, а также не зависят от роли ФОИВ в контексте научно-технологического развития России.

Министерство образования и науки Российской Федерации, являясь, согласно постановлению Правительства Российской Федерации от 03.06.2013 г. № 466 [31], федеральным органом исполнительной власти, осуществляющим функции по выработке и реализации государственной политики и нормативно-правовому регулированию в сфере интеллектуальной собственности (за исключением нормативно-правового регулирования вопросов, относящихся к компетенции Министерства экономического развития Российской Федерации и Федеральной службы по интеллектуальной собственности) не содержит в числе утвержденных для министерства полномочий и функций по выявлению и закреплению интеллектуальных прав. 
Аналогичная особенность справедлива и для нового Министерства науки и высшего образования Российской Федерации, созданного в соответствии постановлением Правительства Российской Федерации от 15.06.2018 г. № 682 [32]. Новому Минобрнауки России предписывается осуществлять функции по выработке и реализации государственной политики в сфере интеллектуальных прав при распоряжении от имени Российской Федерации правами на объекты интеллектуальной собственности и другие научно-технические результаты, созданные за счет средств федерального бюджета по заказу министерства, однако также отсутствуют полномочия и функции по выявлению и закреплению интеллектуальных прав.

Минкомсвязи России, являясь, согласно постановлению Правительства Российской Федерации от 16.11.2015 г. № 1236 [33], уполномоченным федеральным органом исполнительной власти по формированию и ведению реестра российского программного обеспечения и реестра евразийского программного обеспечения, вообще не имеет в числе предоставленных ему полномочий каких-либо функций, касающихся работы с интеллектуальной собственностью, хотя, на практике, и ведет такую деятельность.

На фоне перечисленного, непоследовательным представляется в числе полномочий Федеральной службы по регулированию алкогольного рынка, утвержденных постановлением Правительства Российской Федерации от 24.02.2009 г. № 154 [34], функции по обеспечению закрепления в установленном порядке за Российской Федерацией прав на результаты интеллектуальной деятельности, созданные за счет средств федерального бюджета при реализации государственных контрактов, заключаемых службой (пункт 5.15).

В более общем виде отдельные элементы системы государственной политики и государственного регулирования в сфере интеллектуальной собственности выглядят еще более хаотичными.

Главными акторами, участвующими в государственной политике и государственном регулировании в сфере интеллектуальной собственности, являются:
- Министерство культуры Российской Федерации (Минкультуры России), которое в соответствии с пунктом 1 статьи 1246 Гражданского кодекса Российской Федерации и постановлением Правительства Российской Федерации от 20.07.2011 г. № 590 [35]:

- осуществляет издание нормативных правовых актов в целях регулирования отношений в сфере интеллектуальной собственности, связанных с объектами авторских и смежных прав (в случаях, предусмотренных Гражданским кодексом Российской Федерации);

- осуществляет функции по выработке и реализации государственной политики и нормативно-правовому регулированию в сфере авторского права и смежных прав;

- Министерство науки и высшего образования Российской Федерации (Минобрнауки России), которое в соответствии с постановлением Правительства Российской Федерации от 15.06.2018 г. № 682, осуществляет функции по выработке и реализации государственной политики и нормативно-правовому регулированию в сфере интеллектуальной собственности (за исключением нормативно-правового регулирования вопросов, касающихся контроля, надзора и оказания государственных услуг в сфере правовой охраны изобретений, полезных моделей, промышленных образцов, программ для ЭВМ, баз данных и топологий интегральных микросхем, в том числе входящих в состав единой технологии, товарных знаков, знаков обслуживания, наименований мест происхождения товаров);

- Министерство экономического развития Российской Федерации (Минэкономразвития России), которое в соответствии с постановлением Правительства Российской Федерации от 05.06.2008 г. № 437 [36] осуществляет функции:

- по выработке государственной политики и нормативно-правовому регулированию в области контроля и надзора в сфере правовой охраны и использования результатов интеллектуальной деятельности гражданского, военного, специального и двойного назначения, созданных за счет бюджетных ассигнований федерального бюджета, контроля и надзора в указанной 
сфере деятельности в отношении государственных заказчиков и организаций - исполнителей государственных контрактов, предусматривающих проведение научно-исследовательских, опытно-конструкторских и технологических работ,

- по нормативно-правовому регулированию вопросов, касающихся оказания государственных услуг в сфере правовой охраны изобретений, полезных моделей, промышленных образцов, программ для ЭВМ, баз данных и топологий интегральных микросхем, в том числе входящих в состав единой технологии, товарных знаков, знаков обслуживания и наименований мест происхождения товаров;

- Федеральная служба по интеллектуальной собственности (Роспатент; находится в структуре Минэкономразвития России), которая в соответствии с Указом Президента Российской Федерации от 24.05.2011 г. № 673 и постановлением Правительства Российской Федерации от 21.03.2012 г. № 218 [37] осуществляет функции по:

- правовой защите интересов государства в процессе экономического и гражданско-правового оборота результатов научно-исследовательских, опытно-конструкторских и технологических работ военного, специального и двойного назначения;

- контролю и надзору в сфере правовой охраны и использования результатов интеллектуальной деятельности гражданского, военного, специального и двойного назначения, созданных за счет бюджетных ассигнований федерального бюджета;

- контролю и надзору в установленной сфере деятельности в отношении государственных заказчиков и организаций - исполнителей государственных контрактов, предусматривающих проведение научно-исследовательских, опытно-конструкторских и технологических работ;

- оказанию государственных услуг, в том числе в электронной форме с использованием официального сайта в информационно-телекоммуникационной сети «Интернет», в сфере правовой охраны изобретений, полезных моделей, промышленных образцов, программ для ЭВМ, баз данных и топологий интегральных микросхем, в том числе входящих в состав единой технологии, товарных знаков, знаков обслуживания, наименований мест происхождения товаров;

- Министерство сельского хозяйства Российской Федерации (Минсельхоз России), которое в соответствии с постановлением Правительства Российской Федерации от 12.06.2008 г. № 450 [38] принимает нормативные правовые акты в целях регулирования отношений в сфере интеллектуальной собственности, связанных с селекционными достижениями.

Среди прочих органов, более точечные полномочия предоставлены Федеральной таможенной службе (осуществляет противодействие незаконному обороту объектов интеллектуальной собственности) и Федеральной службе государственной статистики (утверждает формы федерального статистического наблюдения, касающиеся интеллектуальной собственности, и организует сбор соответствующих сведений).

Существует также целый пласт организаций, к компетенции которых отнесены вопросы, находящиеся в плоскости регулирования и управления результатами интеллектуальной деятельности военного, специального и двойного назначения.

Таким образом, в условиях отсутствия единого ФОИВ, который был бы наделен всей полнотой полномочий и ответственности в системе государственной политики и государственного регулирования в сфере интеллектуальной собственности, а также в условиях совпадения зон регулирования и ответственности различных ФОИВ, такая сфера остается без конкретного, ответственного хозяина.

\section{Кодификация правил, условий и принципов управления интеллектуальной собственно- стью, созданной с участием государственного элемента}

Представляется, что обоснованным средством избегания последствий влияния двух последних проблем является подготовка и принятие акта Правительства Российской Федерации, раскрывающего и дополняющего процессуальные и административные лакуны, а также последующий реальный надзор за его соблюдением. 
Рекомендуемый акт должен предусматривать поглощение существующих актов, исключать избыточное взаимодействие и делопроизводство государственного заказчика и исполнителя, а также может предусматривать использование для такого взаимодействия системы государственного учета научно-технической информации и межведомственное взаимодействие с Федеральной службой по интеллектуальной собственности.

Положения, которые подлежат обязательному отражению в таком акте:

- обязательные меры, подлежащие принятию при формировании заказа на выполнение работ, результатом которых являются или могут являться результаты интеллектуальной деятельности, в том числе потребности реального сектора экономики, оценку существующего научного и научно-технического задела, включая результаты, сведения о которых представлены в системах государственного учета результатов НИОКТР военного, специального и двойного назначения и в государственных реестрах Федеральной службы по интеллектуальной собственности;

- критерии принятия решения о создании новых результатов интеллектуальной деятельности при выявлении по результатам оценки уже существующих результатов, отвечающих требованиям, предьявляемым к планируемым к созданию;

- единые и исчерпывающие критерии принятия решения о распределении интеллектуальных прав между исполнителем и Российской Федерацией;

- перечень действий, предпринимаемых государственным заказчиком в случае принятия решения об использовании существующих результатов интеллектуальной деятельности, в том числе об их развитии, модернизации и доработке;

- исчерпывающий перечень уведомлений, сведений и данных, предоставляемых исполнителем государственному заказчику и в случае закрепления исключительного права за исполнителем, и в случае распределения исключительного права в пользу Российской Федерации. При этом, очевидно, объем делопроизводства в приведенных случаях должен различаться как по форме и объему, так и по содержанию, поскольку при закреплении исключительного права за исполнителем государственный заказчик утрачивает возможность влиять на решения исполнителя о способе правовой охраны.

Ввиду возрастания роли и функционала информационных систем, проистекающих из Стратегии, а также из принятых в связи с реализацией Стратегии и «майского указа» актов Правительства Российской Федерации, в том числе постановлений от 17.01.2018 № 16 г. [39] и от 07.04.2018 г. № 421 [40], и проекта федерального закона «О научной научно-технической и инновационной деятельности в Российской Федерации», взаимодействие государственных заказчиков с исполнителями целесообразно предусматривать в модернизируемых и создаваемых информационных системах. К таковым относятся создаваемые (предусмотренные к созданию) единая цифровая платформа научного и научно-технического взаимодействия, цифровая система управления сервисами научной инфраструктуры коллективного пользования;

- рекомендуемые проекты договоров, государственных (муниципальных) контрактов и соглашений о предоставлении субсидии (гранта) либо их элементов, оказывающих влияние на создание результатов интеллектуальной деятельности и предоставление им правовой охраны, в том числе условий обязательного и добровольного проведения патентных исследований, распределение обязательств о последующем внедрении результатов интеллектуальной деятельности и ответственность за их неисполнение;

- рекомендуемый набор критериев принятия решения о способе предоставления правовой охраны результатам интеллектуальной деятельности, исключительное право на которые принадлежит Российской Федерации, в том числе за рубежом, взаимоувязанных с расходами, предусмотренными на предоставление такой охраны, принятия решений о поддержании 
правовой охраны и о распоряжении исключительным правом;

- рекомендуемые условия о размере вознаграждения авторов (относящихся к исполнителю, подрядчику) результатов интеллектуальной деятельности, обладающих признаками служебных, находящегося, в частности, в зависимости от доли доходов, приходящейся на использование результата при реализации товаров (работ, услуг), либо от доли экономии, возникшей за счет использования результата при реализации товаров (работ, услуг);

- рекомендуемый набор сценариев действий государственного заказчика в случае получения уведомлений, сведений и данных, предоставляемых исполнителем, являющемся обладателем исключительного права на результат интеллектуальной деятельности, а также набор критериев принятия решения о требовании предоставления права использования такого результата третьему лицу;

- рекомендуемый порядок «приемки» результатов интеллектуальной деятельности, включающий анализ полученных результатов научно-технической деятельности, выявление из них охраняемых и охраноспособных результатов интеллектуальной деятельности, принятие решений об отнесении исключительного права на результаты интеллектуальной деятельности к объектам нематериальных активов, определении их первоначальной стоимости в случае, когда их количество составляет два и более, как и уточненные условия отнесения исключительного права к объектам нематериальных активов. Более того, государственная экспертиза, проводимая при государственной регистрации объектов патентных прав в таком акте может отчасти заменить собой деятельность государственного заказчика по оценке качеств полученных результатов;

- исчерпывающий перечень обязательных мер, подлежащих принятию с целью максимального внедрения результатов интеллектуальной деятельности, исключительное право на которые принадлежит
Российской Федерации, в том числе меры по взаимодействию с институтами развития и государственными компаниями, а также реальным сектором экономики, по включению оборота прав на результаты в документы стратегического планирования и результатов в единый реестр российских программ для ЭВМ и баз данных, а также мониторинга внедрения результатов интеллектуальной деятельности, исключительное право на которые принадлежит не только Российской Федерации, но и исполнителям;

- меры государственной поддержки, применяемые для поощрения лиц, обеспечивающих создание и внедрение результатов интеллектуальной деятельности, полученных с использованием бюджетных средств, в том числе таких произведений науки, включая меры ответственности за невыплату такого вознаграждения. В качестве основы для выработки таких мер могут быть использованы положения, предусмотренные в статье 34 Закона СССР от 31.05.1991 г. № 2213-1 «Об изобретениях в СССР»;

- унифицированные подходы к государственному учету работ и результатов гражданского, военного, специального и двойного назначения, с разграничением условий сохранения конфиденциальности информации и ее распространения.

Принятие акта, содержащего все обозначенные вопросы, потребует изменения подходов к контролю и надзору в сфере правовой охраны и использования результатов интеллектуальной деятельности, созданных за счет или с использованием бюджетных средств, что отвечает совершенствованию контрольно-надзорной деятельности, включенному в перечень мер государственной политики по достижению национальных целей развития, предусмотренных Основными направлениями деятельности Правительства Российской Федерации на период до 2024 г. [41].

Анализ принятия мер, касающихся результатов интеллектуальной деятельности, предусматриваемых отдельными издаваемыми Правительством Российской Федерации актами, показывает, 
что, в отсутствие прямо определенных функций и полномочий, ФОИВ не хватает ресурсов на их принятие. При этом даже в случае создания мегарегулятора в сфере интеллектуальной собственности, сложно представить, что появление результатов интеллектуальной деятельности в деятельности иных ФОИВ будет прекращено.

Кроме того, как известно, следующие нормативные акты требуют, чтобы для работы с результатами интеллектуальной деятельности в ФОИВ создавались следующие структуры:

- инвентаризационная комиссия, согласно постановлению Правительства РФ от 14.01.2002 г. № 7;

- комиссия по поступлению и выбытию активов учреждения, согласно приказу Минфина России от 01.12.2010 г. № 157н;

- комиссия по рассмотрению вопросов о целесообразности принятия отдельных решений, связанных с распоряжением интеллектуальными правами на результаты интеллектуальной деятельности (существование структуры проистекает из опыта применения Правил управления правами РФ на РИД, выраженном в приказах Минобрнауки России от 29.09.2014 г. № 1293, Минздрава России от 27.07.2016 г. № 539н, Минкомсвязи России от 16.02.2016 г. № 48, Минсельхоза России от 11.10.2016 г. № 447, Росархива от 21.02.2018 г. № 23).

Создание специализированного подразделения, осуществляющего в ФОИВ функции, имеющие непосредственное отношение к работе с результатами интеллектуальной деятельности, которое должно будет обеспечить выполнение задач, поставленных перед вышеуказанными структурами, может быть предусмотрено в проекте федерального закона «О научной, научно-технической и инновационной деятельности в Российской Федерации», находящемся в Правительстве Российской Федерации или готовящемся к очередному внесению в него.

Подобный опыт создания тематических специализированных подразделений не новый для российского законодательства. Одним из последних случаев создания таких подразделений можно назвать создание в 2013 г. контрактной службы, которое предусмотрено Федеральным законом от 05.04.2013 г. № 44-Ф3 «О контрактной системе в сфере закупок товаров, работ, услуг для обеспечения государственных и муниципальных нужд». Согласно статьи 38 указанного федерального закона, контрактная служба централизованно осуществляет большинство полномочий в сфере закупок.

Таким образом, предлагается прямо вменить ФОИВ в пределах предусмотренной для них сферы деятельности, как минимум, обязанности по обеспечению:

- выявления результатов интеллектуальной деятельности и обоснованного распределения интеллектуальных прав;

- предоставления обоснованной правовой охраны создаваемым результатам интеллектуальной деятельности;

- распоряжения интеллектуальными правами на результаты интеллектуальной деятельности, правообладателем которых является Российская Федерация;

- внедрения и контроля внедрения результатов интеллектуальной деятельности;

- государственного учета результатов интеллектуальной деятельности.

В заключение не представляется возможным обойти стороной еще один важный аспект.

На очередном совещании главы страны с членами Правительства Российской Федерации, прошедшем 02.10.2018 г., В.В. Путин обозначил важность реального, на практике достижения целевых показателей «майского указа», выхода на рубежи, обозначенные в нем [42]. 29.09.2018 г. Правительством Российской Федерации были утверждены Основные направления деятельности Правительства Российской Федерации на период до 2024 года (далее ОНДП), положения которых были презентованы Президенту Российской Федерации на прошедшем очередном совещании. ОНДП определяют цели, основные задачи и приоритеты деятельности Правительства Российской Федерации по осуществлению прорывного научно-технологического и социально-экономического развития.

В целях выполнения «майского указа» ОНДП предусматривают совершенствование текущей инфраструктуры исследований, разработок 
и инновации, и решение отдельных задач, релевантным президентским целям, например, повышение патентной активности российских заявителей (пункт 4 ОНДП).

Цель по вхождению России в число пяти крупнейших экономик мира планируется достигать, в частности, за счет создания конкурентоспособной на мировом рынке продукции через кооперацию организаций реального сектора экономики с научными и образовательными организациями и реализацию проектов полного инновационного цикла, включая комплексные научно-технические проекты (пункт 6 ОНДП). При этом, функционально сходным с таким решением выглядит формирование благоприятной среды для внедрения новых разработок в производство, в том числе развитие инфраструктуры прикладных исследований и опытно-конструкторских разработок, являющееся приоритетом в развитии отраслей промышленности, которое применяется уже для цели создания в базовых отраслях экономики высокопроизводительных экспортно-ориентированных секторов, развивающихся на основе современных технологий и обеспеченных высококвалифицированными кадрами (пункт 7 ОНДП). Однако, в тексте ОНДП не уточняется, являются ли такие инструменты едиными средствами достижения разных целей «майского указа». Если они таковыми не являются, в чем причина и где граница демаркации таких инструментов в механизме выполнения «майского указа».

Важнейшим положением ОНДП, к которому относятся и которому удовлетворяют как три обозначенных авторами проблемы, так и предлагаемые авторами способы решения таких проблем, является положение о реализации «регуляторной гильотины», предусматривающей обновление всех обязательных требований, принятых ранее середины 2010 г. с одновременным проведением анализа фактических положительных (отрицательных) последствий принятия нормативных правовых актов, а также достижения заявленных целей регулирования.

Следует, однако, учитывать, что решение задачи по повышению патентной активности, само по себе, не увеличивает плодотворность кооперации организаций реального сектора экономики с научными и образовательными организациями, а также не приближает возникновение инновационной продукции и повышение ее конкурентоспособности. Подобное заблуждение проецируется и в часто упоминаемой в настоящей статьей ФЦП ИиР.

Показатель патентной активности демонстрирует лишь число заявок или патентов, соответственно, поданных или полученных в определенных патентных ведомствах. Распространенное формирование на базе такого показателя выводов о развитии сектора исследований и разработок всегда обусловлено допущениями, применяемыми в известной степени.

Даже на терминологическом уровне в корне такой задачи скрывается западня, обусловленная тем, что не все результаты интеллектуальной деятельности могут быть объектами, участвующими в патентовании, а некоторые из них вовсе не допущены до такой процедуры. То есть, патентная активность не отображает действительной результативности сектора исследований и разработок, и, вероятно, искажает ее.

В этой связи, показатель «число ...патентных заявок...», предусмотренный в ФЦП ИиР, обращает на себя особое внимание. Объем термина «патентные заявки» в российском законодательстве не имеет понятного и однозначного толкования. В узкой интерпретации к нему относятся только те объекты, в отношении которых поданы заявки на выдачу патентов, то есть он не включает в себя, например, программы для ЭВМ, базы данных, топологии интегральных микросхем. В широкой интерпретации, термин «патентные заявки» может включать в себя программы для ЭВМ, базы данных и топологии интегральных микросхем, на которые поданы заявки на государственную регистрацию, но не имеет определенных пределов.

Таким образом, наиболее объективным показателем, который способствует ускорению технологического развития Российской Федерации, увеличению количества организаций, осуществляющих технологические инновации, развитию института интеллектуальной собственности, является многомерный показатель, касающийся результатов интеллектуальной деятельности (РИД), видоизменяющийся в формулировке и значении в зависимости от степени 
продвижения соответствующих программ, мероприятий и проектов. Например, от числа созданных охраноспособных и охраняемых РИД к числу ставших нематериальными активами; к числу имеющих документальное подтверждение использования; и пр. Применение такого показателя позволит не только оценить количественный прирост изобретательской и творческой активности населения (вместо «патентной активности»), но и качество создаваемых результатов интеллектуальной деятельности по мере ответа открытого рынка на такие результаты. Однако, ввиду непрогнозируемости их достижения и многофакторности их достижения, такие показатели допустимо применять лишь для мониторинга продвижения программ, мероприятий и проектов, оценки эффектов от них, но не в качестве меры ответственности.

\section{ЗАКЛЮЧЕНИЕ}

В условиях, когда Президентом Российской Федерации определены требования к технологическому прогрессу, очевидно, что работа с результатами интеллектуальной деятельности, создаваемыми за счет или с использованием бюджетных средств, не может вестись стохастически или по остаточному принципу.

Правительство Российский Федерации ясно понимает лакуны, которые свойственны механизмам управления государственным имуществом. Так, например, отсутствие унифицированных подходов к оценке потребности в имуществе (интеллектуальной собственности как вида имущества) и недостаточность контроля за распоряжением и использованием имущества прямо названы в числе системных проблем распоряжением Правительства РФ от 31.01.2019 г. № 117-р [43].

В этой связи примечателен и тот факт, что 31.07.2018 г. «новый» Минобрнауки России совместно с Всемирной организацией интеллектуальной собственности в числе одного из первых документов утвердил типовое положение «Политика в области интеллектуальной собственности для университетов и научно-исследовательских организаций» [44]. Возникает надежда на то, что вопросы интеллектуальной собственности приобретут в новом министерстве особую важность.
Реализация Стратегии, «майского указа» или других документов, принятых либо применяемых в связи с ними, путем создания надстроек и улучшений, построенных на базе системы, имеющей бреши, таит в себе риск недостижения устойчивого, динамичного и сбалансированного научно-технологического развития Российской Федерации.

Массовое появление охраняемых или охраноспособных результатов, для которых отсутствуют потребители и сохраняется высокая степень неопределенности места их приложения в инновационном цикле тех или иных продуктов, нивелирует эффективность любой системы обязательных или дополнительных мер, предпринимаемых в целях управления правами на результаты интеллектуальной деятельности.

Таким образом, помимо устранения неопределенностей, возникающих ввиду особого субсидийного оформления финансирования НИОКТР, авторами предлагается разработать и принять единый акт Правительства Российской Федерации, определяющий основные и современные принципы и меры по управлению правами на результаты интеллектуальной деятельности, создаваемые за счет или с использованием бюджетных средств. Правила должны охватывать весь управленческий цикл, начиная от формирования заказа, условий и оснований распределения прав на результаты интеллектуальной деятельности, наделяющий ФОИВы всей полнотой полномочий и ответственности в системе государственной политики и государственного регулирования в сфере управления интеллектуальной собственностью, создаваемой при финансировании соответствующего ФОИВ.

Аналогичный подход, обеспечивающий достаточное единообразие, необходим при обосновании обязательств по обеспечению доведения разработок до стадии промышленного применения и реализации готовой продукции, а также обязательств лица, реализующего в производственной практике РНТД, завершая обязательствами по мониторингу использования результатов интеллектуальной деятельности и принятию решений об обоснованности создания, поддержания правовой охраны, распоряжения правами и использования результатов интеллектуальной деятельности. 


\section{ЛИТЕРАТУРА}

1. Указ Президента РФ от 01 декабря 2016 г. № 642 (2016) О Стратегии научно-технологического развития Российской Федерации / Официальный сайт Президента России. http://kremlin. ru/acts/bank/41449.

2. Указ Президента РФ от 07 мая 2018 г. № 204 (2018) О национальных целях и стратегических задачах развития Российской Федерации на период до 2024 года / Официальный сайт Президента России. http://kremlin.ru/acts/bank/43027.

3. Указ Президента РФ от 22 июля 1998 г. № 863 (1998) О государственной политике по вовлечению в хозяйственный оборот результатов научно - технической деятельности и объектов интеллектуальной собственности в сфере науки и технологий / Законодательная база Российской Федерации. https://zakonbase.ru/content/ base/27856.

4. Послание Президента Федеральному Собранию (2018) / Официальный сайт Президента России, 01.03.2018. http://kremlin.ru/events/president/ news/56957.

5. Статья 128. Объекты гражданских прав (2019) Гражданский кодекс РФ (часть первая) в ред. от 03 августа 2018 г. / КонсультантПлюс. http://www.consultant.ru/document/cons_doc LAW_5142/f7871578ce9b026c450ł64790704b $\bar{d}$ $48 \mathrm{c} \overline{\mathrm{d}} 94 \mathrm{bcb}$.

6. Федулкин Д.П., Зинов В.Г. (2018) Проблемы инвентаризации результатов интеллектуальной деятельности, полученных в ходе выполнения государственных контрактов // Экономика науки. T. 4. № 3. C. 210-226.

7. Постановление Правительства РФ от 21 мая 2013 г. № 426 (2015) О федеральной целевой программе «Исследования и разработки по приоритетным направлениям развития научно-технологического комплекса России на 2014-2020 годы» / Гарант. http://base.garant.ru/70385450.

8. Бюджетный кодекс РФ От 31 июля 1998 г. № 145-Ф3 (1998) / Гарант. http://base.garant. ru/ 12112604.

9. Постановление Правительства РФ от 25 сентября 2017 г. № 1156 (2017) О внесении изменений в федеральную целевую программу «Исследования и разработки по приоритетным направлениям развития научно-технологического комплекса России на 2014-2020 годы» / ФЦП Ии P. http://www.fcpir.ru/upload/iblock/701/ postanovlnie-pravitelstva-rf-ot-30.12.2015-n-1519. pdf-_adobe-acrobat-pro.pdf.

10. Федеральный закон РФ от 18 июля 2011 г. № 223-Ф3 (2011) О закупках товаров, работ, услуг отдельными видами юридических лиц / Гарант. http://base.garant.ru/12188083.
11. Федеральный закон РФ от 05 апреля 2013 г. № 44-Ф3 (2013) О контрактной системе в сфере закупок товаров, работ, услуг для обеспечения государственных и муниципальных нужд / Гарант. http://base.garant.ru/70353464.

12. Гражданский кодекс Российской Федерации (1994) / Гарант. http://base.garant.ru/10164072.

13. Курбатова С.С. (2015) Проблемы правовой природы договоров о субсидировании // Актуальные проблемы российского права. №4. С. 126-132.

14. Постановление Арбитражного суда Волго-Вятского округа от 26 октября 2015 г. № Ф0141 18/2015 по делу № А82-11937/2012 (2015) Арбитражный суд Волго-Вятского округа.

15. Постановление Правительства РФ от 02 сентября 1999 г. № 982 (1999) Об использовании результатов научно-технической деятельности / Гарант. http://base.garant.ru/180853.

16. Распоряжение Правительства РФ от 30 ноября 2001 г. № 1607-р (2001) Об основных направлениях реализации государственной политики по вовлечению в хозяйственный оборот результатов научно - технической деятельности / ФИПС. http://wwwl.fips.ru/wps/wcm/connect/ content_ru/ru/documents/russian_laws/dictation_ government_rf/paspor_rf_1607_30112001.

17. Постановление Правительства РФ от 22 апреля 2009 г. № 342 (2009) О некоторых вопросах регулирования закрепления прав на результаты научно-технической деятельности / Гарант. http:// www.garant.ru/products/ipo/prime/doc/95440.

18. Постановление Правительства РФ от 17 ноября 2005 г. № 685 (2005) О порядке распоряжения правами на результаты научно-технической деятельности / Гарант. http://base.garant.ru/188851.

19. Постановление Правительства РФ от 22 марта 2012 г. № 233 (2012) Об утверждении Правил осуществления государственными заказчиками управления правами Российской Федерации на результаты интеллектуальной деятельности гражданского, военного, специального и двойного назначения / Гарант. http://base.garant. ru/70153000.

20. Указ Президента РФ от 24 мая 2011 г. № 673 (2011) О Федеральной службе по интеллектуальной собственности / КонсультантПлюс. http://www.consultant.ru/document/cons_doc_ LAW_114249.

21. Постановление Правительства РФ от 26 февраля 2002 г. № 131 (2002) О государственном учете результатов научно-исследовательских, опытно-конструкторских и технологических работ военного, специального и двойного назначения / КонсультантПлюс. http://www.consultant. ru/document/cons_doc_LAW_35674. 
22. Постановление Правительства РФ от 12 апреля 2013 г. № 327 (2013) О единой государственной информационной системе учета научно-исследовательских, опытно-конструкторских и технологических работ гражданского назначения / Российская газета. https://rg.ru/2013/04/22/ uchet-site-dok.html.

23. Письмо Минобрнауки России от 09 июня 2016 г. № 14-930 (2016) О разъяснении действующего законодательства / PРT. http://ppt.ru/docs/ pismo/minobrnauki.

24. Постановление Правительства РФ от 07 апреля 2018 г. № 421 (2018) Об утверждении Правил разработки и корректировки Стратегии научно-технологического развития Российской Федерации и Правил мониторинга реализации Стратегии научно-технологического развития Российской Федерации / Гарант. https://www. garant.ru/products/ipo/prime/doc/71818316.

25. Постановление Правительства РФ от 14 января 2002 г. № 7 (2002) О порядке инвентаризации и стоимостной оценке прав на результаты научно-технической деятельности / Гарант. http:// base.garant.ru/5182068.

26. Приказ Минфина России от 01 декабря 2010 г. № 157н (2010) Об утверждении Единого плана счетов бухгалтерского учета для органов государственной власти (государственных органов), органов местного самоуправления, органов управления государственными внебюджетными фондами, государственных академий наук, государственных (муниципальных) учреждений и Инструкции по его применению / Гарант. http:// base.garant.ru/12180849.

27. Приказ Минфина России от 27 декабря 2007 г. № 153н (2007) Об утверждении Положения по бухгалтерскому учету «Учет нематериальных активов» (ПБУ 14/2007) / Гарант. http://base. garant.ru/12158476.

28. Приказ Минфина России от 28 декабря 2015 г. № 217н (2015) О введении Международных стандартов финансовой отчетности и Разьяснений Международных стандартов финансовой отчетности в действие на территории Российской Федерации и о признании утратившими силу некоторых приказов (отдельных положений приказов) Министерства финансов Российской Федерации / КонсультантПлюс. http://www.consultant.ru/document/cons_doc_ LAW_193532.

29. Распоряжение Минобрнауки России от 24 февраля 2016 г. № P-25 (2016) О принятии решения о возможности заключения договора о безвозмездном отчуждении исключительного права на результат интеллектуальной деятельности на условиях, предусмотренных пунктом 18(1) Правил осуществления государственными заказчиками управления правами Российской Федерации на результаты интеллектуальной деятельности гражданского, военного, специального и двойного назначения, утвержденных постановлением Правительства Российской Федерации от 22 марта 2012 г. № 233 / Минобрнауки России. https:// xn-80abuciiibhv9a.xn - plai/\%D0\%B4\%D0\%BE\% D0\%BA\%D 1\%83\%D0\%BC\%D0\%B5\%D0\%BD\%D 1 $\% 82 \% \mathrm{D} 1 \% 8 \mathrm{~B} / 7922$.

30. Постановление Президиума Суда по интеллектуальным правам От 16 марта 2018 г. № С0121/2018 по делу № СИП-733/2016 (2018) / Суд по интеллектуальным правам.

31. Постановление Правительства РФ от 03 июня 2013 г. № 466 (2013) Об утверждении Положения о Министерстве образования и науки Российской Федерации / Гарант. http://base.garant. ru/70392898.

32. Постановление Правительства РФ от 15 июня 2018 г. № 682 (2018) Об утверждении Положения о Министерстве науки и высшего образования Российской Федерации и признании утратившими силу некоторых актов Правительства Российской Федерации / Гарант. http://www. garant.ru/products/ipo/prime/doc/71868584.

33. Постановление Правительства РФ от 16 ноября 2015 г. № 1236 (2015) Об установлении запрета на допуск программного обеспечения, происходящего из иностранных государств, для целей осуществления закупок для обеспечения государственных и муниципальных нужд / Гарант. http://base.garant.ru/71252170.

34. Постановление Правительства РФ от 24 февраля 2009 г. № 154 (2009) О Федеральной службе по регулированию алкогольного рынка / КонсультантПлюс. http://www.consultant.ru/ document/cons_doc_LAW_85367.

35. Постановление Правительства РФ от 20 июля 2011 г. № 590 (2011) О Министерстве культуры Российской Федерации / Гарант. http://base. garant.ru/12188356.

36. Постановление Правительства РФ от 05 июня 2008 г. № 437 (2008) О Министерстве экономического развития Российской Федерации / Гарант. http://base.garant.ru/12160901.

37. Постановление Правительства РФ от 21 марта 2012 г. № 218 (2012) О Федеральной службе по интеллектуальной собственности / Гарант. http:// base.garant.ru/70152984.

38. Постановление Правительства РФ от 12 июня 2008 г. № 450 (2008) О Министерстве сельского хозяйства Российской Федерации / Гарант. http://base.garant.ru/12160970.

39. Постановление Правительства РФ от 17 января 2018 г. № 16 (2018) Об утверждении Положения о создании и функционировании советов по приоритетным направлениям научно-технологического развития Российской Федерации / ФЦП Ии Р. http://www.fcpir.ru/events_and_publications/_doc/ 
postanovlenie-pravitelstva-rossiyskoy-federatsiiot-17-yanvarya-2018-g-16-ob-utverzhdeniipolozheniya.

40. Постановление Правительства РФ от 07 апреля 2018 г. № 421 (2018) Об утверждении Правил разработки и корректировки Стратегии научно-технологического развития Российской Федерации и Правил мониторинга реализации Стратегии научно-технологического развития Российской Федерации / КонсультантПлюс. http://www.consultant.ru/document/cons_doc_ LAW_295346.

41. Постановление Правительства РФ от 4 августа 2015 г. № 789 (2015) Основные направления деятельности Правительства Российской Федерации на период до 2024 года / Официальный сайт Правительства России. http://government. ru/news/34168.

42. Совещание с членами Правительства (2018) / Официальный сайт Президента России. http:// www.kremlin.ru/events/president/news/58684.

43. Распоряжение Правительства РФ от 31 января 2019 г. № 117-р (2019) Об утверждении Концепции повышения эффективности бюджетных расходов в 2019-2024 годах / КонсультантПлюс. http://www.consultant.ru/document/cons_doc LAW_317187.

44. Политика в области интеллектуальной собственности для университетов и научно-исследовательских организаций (2019) Типовое положение / Минобрнауки России. URL: http://minobrnauki. gov.ru/ru/documents/card/?id_4=48.

\section{REFERENCES}

1. Decree of the President of the Russian Federation dated 01 December 2016 № 642 (2016) On the Strategy of the Scientific and Technological Development of the Russian Federation / Official website of the President of Russia. http://kremlin.ru/ acts/bank/41449.

2. Decree of the President of the Russian Federation dated 07 May 2018 № 204 (2018) On the national goals and strategic objectives of the development of the Russian Federation for the period up to 2024 / Official web-site of the President of Russia. http://kremlin.ru/acts/bank/43027.

3. Decree of the President of the Russian Federation dated 22 July 1998 № 863 (1998) On the state policy on engaging in economic circulation the results of scientific and technical activities and objects of intellectual property in the field of science and technology / Legislative base of the Russian Federation. https://zakonbase.ru/content/base/27856.

4. Presidential Address to the Federal Assembly (2018) / Official web-site of the President of Russia, 01.03.2018. http://kremlin.ru/events/president/ news/56957.

5. Article 128. Objects of civil rights (2019) Civil Code of the Russian Federation (Part One) dated 03 August 2018 / Consultant Plus. http://www. consultant.ru/document/cons_doc_LAW_5142/

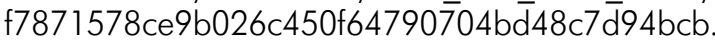

6. Fedulkin D.P., Zinov V.G. (2018) Problems of inventory of the results of intellectual activity obtained in the implementation of state contracts // The Economics of Science. V. 4. № 3. P. 210-226.

7. Decree of the Government of the Russian Federation dated 21 May 2013 № 426 (2015) On the federal target program «Research and development in priority areas of development of the scientific and technological complex of Russia for 2014-2020» / Garant. http://base.garant.ru/70385450.

8. The Budget Code of the Russian Federation dated 31 July 1998 № 145-Ф3 (1998) / Garant. http:// base.garant.ru/12112604.

9. Decree of the Government of the Russian Federation dated 25 September 2017 № 1156 (2017) On Amending the Federal Target Program «Research and Development in Priority Areas for the Development of the Scientific and Technological Complex of Russia for 2014-2020» / FCPIR. http://www. fcpir.ru/upload/iblock/701/postanovlnie-pravitelstva-rf-ot-30.12.2015-n-1519.pdf-_-adobe-acrobat-pro.pdf.

10. Federal Law of the Russian Federation dated 18 July 2011 № 223-Ф3 (2011) On the procurement of goods, works, services by certain types of legal entities / Garant. http://base.garant.ru/12188083.

11. Federal Law of the Russian Federation dated 05 April 2013 № 44-Ф3 (2013) On the contract system in the field of procurement of goods, works, services for state and municipal needs / Garant. http://base.garant.ru/70353464.

12. Civil Code of the Russian Federation (1994) / Garant. http://base.garant.ru/10164072.

13. Kurbatov S.S. (2015) Problems of the legal nature of subsidy agreements // Actual problems of Russian law. № 4. P. 126-132.

14. Decree of the Arbitration Court of the Volga-Vyatka District dated 26 October 2015 № Ф01$4118 / 2015$ on case № A82-11937/2012 (2015) Arbitration Court of the Volga-Vyatka District.

15. Decree of the Government of the Russian Federation dated 02 September 1999 № 982 (1999) On the use of the results of scientific and technological activities / Garant. http://base.garant.ru/180853. 
16. Order of the Government of the Russian Federation dated 30 November 2001 № 1607-p (2001) On the main directions of implementation of the state policy for engaging the results of scientific and technical activity / FIPS. http://wwwl.fips.ru/ wps/wcm/connect/content_ru/ru/documents/ russian_laws/dictation_government_rf/paspor_ rf_1607_30112001.

17. Decree of the Government of the Russian Federation dated 22 April 2009 № 342 (2009) On some issues of regulation of securing rights to the results of scientific and technical activities / Garant. http:// www.garant.ru/products/ipo/prime/doc/95440.

18. Decree of the Government of the Russian Federation dated 17 November 2005 № 685 (2005) On the Procedure for Managing Rights to the Results of Scientific and Technical Activities / Garant. http:// base.garant.ru/188851.

19. Decree of the Government of the Russian Federation dated 22 March 2012 № 233 (2012) On Approving the Rules for Government Customers to Manage the Rights of the Russian Federation to the Results of Intellectual Activities of Civil, Military, Special and Dual Purpose / Garant. http://base. garant.ru/70153000.

20. Decree of the President of the Russian Federation dated 24 May 2011 № 673 (201 1) On the Federal Service for Intellectual Property / Consultant Plus. http://www.consultant.ru/document/cons_doc_ LAW_114249.

21. Decree of the Government of the Russian Federation dated 26 February 2002 № 131 (2002) On the state accounting of the results of research, development and technological works of military, special and dual use / Consultant Plus. http://www.consultant.ru/document/cons doc LAW 35674.

22. Decree of the Government of the Russian Federation dated 12 April 2013 № 327 (2013) On a unified state information system for accounting civilian research and development and technological works / Rossiyskaya Gazeta. https:// rg.ru/2013/04/22/uchet-site-dok.html.

23. Letter of the Ministry of Education and Science of the Russian Federation dated 09 June 2016 № 14930 (2016) Clarification of current legislation / PPT. http://ppt.ru/docs/pismo/minobrnauki.

24. Decree of the Government of the Russian Federation dated 07 April 2018 № 421 (2018) On Approving the Rules for Developing and Adjusting the Strategy for the Scientific and Technological Development of the Russian Federation and the Rules for Monitoring the Implementation of the Strategy for the Scientific and Technological Development of the Russian Federation / Garant. https://www.garant. ru/products/ipo/prime/doc/71818316.

25. Decree of the Government of the Russian Federation dated 14 January 2002 № 7 (2002) On the procedure for inventory and valuation of rights to the results of scientific and technical activities / Garant. http://base.garant.ru/5182068.

26. Order of the Ministry of Finance of Russia dated 01 December 2010 № 157n (2010) On approval of the Unified Chart of Accounts for state authorities (state bodies), local governments, government bodies of state extra-budgetary funds, state academies of sciences, state (municipal) institutions and instructions for its use / Garant. http://base.garant. ru/12180849.

27. Order of the Ministry of Finance of Russia dated 27 December 2007 № 153n (2007) On Approval of the Accounting Regulation «Accounting for Intangible Assets» (PBU14/2007) / Garant. http://base. garant.ru/12158476.

28. Order of the Ministry of Finance of Russia dated 28 December 2015 № 217n (2015) On the Introduction of International Financial Reporting Standards and Explanations of International Financial Reporting Standards into force in the Russian Federation and on the recognition of certain orders (certain provisions of orders) of the Ministry of Finance of the Russian Federation / Consultant Plus. http://www. consultant.ru/document/cons_doc_LAW_193532.

29. Order of the Ministry of Education and $\bar{S}$ cience of Russia dated 24 February 2016 № P-25 (2016) On making a decision on the possibility of concluding an agreement on the gratuitous alienation of the exclusive right to the result of intellectual activity under the conditions stipulated in paragraph 18 (1) of the Rules for the implementation by government customers of rights management in Federation on the results of intellectual activities of civil, military, special and dual use, approved by the Government of the Russian Federation dated 22 March 2012 № 233 / The Ministry of Education and Science of Russia. https://xn-80abuciiibhv9a.xn - plai/\%D0\% B4\%D0\%BE\%D0\%BA\%D 1\%83\%D0\%BC\%D0\%B5 $\% \mathrm{D0} \% \mathrm{BD} \% \mathrm{D} 1 \% 82 \% \mathrm{D} 1 \% 8 \mathrm{~B} / 7922$.

30. Resolution of the Presidium of the Court on Intellectual Rights dated 16 March 2018 № C0121/2018 on case № SIP-733/2016 (2018) / Court on Intellectual Property Rights.

31. Decree of the Government of the Russian Federation dated 03 June 2013 № 466 (2013) On the approval of the Regulation on the Ministry of Education and Science of the Russian Federation / Garant. http://base.garant.ru/70392898.

32. Decree of the Government of the Russian Federation dated 15 June 2018 № 682 (2018) On the approval of the Regulation on the Ministry of Science and Higher Education of the Russian Federation and the recognition of certain acts of the Government of the Russian Federation / Garant. http://www. garant.ru/products/ipo/prime/doc/71868584.

33. Decree of the Government of the Russian Federation dated 16 November 2015 № 1236 (2015) On the prohibition of the admission of software 
originating from foreign countries for the purposes of procurement for state and municipal needs / Garant. http://base.garant.ru/71252170.

34. Decree of the Government of the Russian Federation dated 24 February 2009 № 154 (2009) On the Federal Service for the Regulation of the Alcohol Market / ConsultantPlus. http://www.consultant.ru/ document/cons_doc_LAW_85367.

35. Decree of the Government of the Russian Federation dated 20 July 2011 № 590 (2011) On the Ministry of Culture of the Russian Federation / Garant. http://base.garant.ru/12188356.

36. Decree of the Government of the Russian Federation dated 05 June 2008 № 437 (2008) On the Ministry of Economic Development of the Russian Federation / Garant. http://base.garant.ru/12160901.

37. Decree of the Government of the Russian Federation dated 21 March 2012 № 218 (2012) On the Federal Service for Intellectual Property / Garant. http://base.garant.ru/70152984.

38. Decree of the Government of the Russian Federation dated 12 June 2008 № 450 (2008) On the Ministry of Agriculture of the Russian Federation / Garant. http://base.garant.ru/12160970.

39. Decree of the Government of the Russian Federation dated 17 January 2018 № 16 (2018) On the approval of the Provision on the establishment and operation of councils in the priority areas of scientific and technological development of the Russian Federation / FCPIR. http://www.fcpir.ru/events and_publications/_doc/postanovlenie-pravitelstva- rossiyskoy-federatsii-ot-17-yanvarya-2018-g-16-obutverzhdenii-polozheniya.

40. Decree of the Government of the Russian Federation dated 07 April 2018 № 421 (2018) On Approving the Rules for Developing and Adjusting the Strategy for the Scientific and Technological Development of the Russian Federation and the Rules for Monitoring the Implementation of the Strategy for the Scientific and Technological Development of the Russian Federation / Consultant Plus. http://www. consultant.ru/document/cons_doc_LAW_295346.

41. Decree of the Government of the Russian Federation dated 4 April 2015 № 789 (2015) The main activities of the Government of the Russian Federation for the period up to 2024 / Official web-site of the Government of Russia. http://government.ru/ news/34168.

42. Meeting with members of the Government (2018) / Official web-site of the President of Russia. http:// www.kremlin.ru/events/president/news/58684.

43. Order of the Government of the Russian Federation dated 31 January 2019 № 117-p (2019) On the Approval of the Concept for Increasing the Efficiency of Budgetary Expenditures in 2019-2024 / Consultant Plus. http://www.consultant.ru/document/cons_doc_LAW_317187.

44. Intellectual property policy for universities and research organizations (2019) Model Provision / Ministry of Education and Science of the Russian Federation. URL: http://minobrnauki.gov.ru/ru/ documents/card/?id_4=48.

UDC 338.28

I Fedulkin D.P., Zinov V.G. Problems of management of rights to the results of intellectual activity created I using budget funds (Directorate of State Scientific and Technical Programmes, Presnensky Val Street, 19,

I building 1, Moscow, Russia, 123557; The Russian Presidential Academy of National Economy and Public

1 Administration, prospect Vernadskogo, 82, Moscow, Russia, 119571)

I Abstract. The article analyzes the problems arising from the commercialization of scientific results obtained using

I budgetary funds, due to the unresolved number of fundamental issues of managing the rights to such results of

I intellectual activity. The legal uncertainty of the agreement on the provision of subsidies for budget financing of

I research and the lack of a unified methodology for managing the rights of the Russian Federation to the obtained

I scientific and technical results are revealed. The authors showed that significant budgetary funds allocated for

1 research in the framework of full life cycle projects, in the absence of a codified set of rules for creating intellectual

I property, cause serious problems in terms of the country's successful scientific and technological development.

I As real measures to overcome the causes that are the source of risks for the implementation of ambitious plans for

I the scientific and technological development of the economy, the authors propose to develop and adopt uniform

I rules defining principles and measures for managing rights to the results of intellectual activity, ranging from the

I formation of an order, conditions and grounds for the distribution of rights to results of intellectual activity, as well

I as giving the Federal Agency full of powers and responsibility in the system of state policy. The proposed approach

I is necessary in justifying commitments to bring the development to the stage of industrial application and sale of

I finished products, as well as commitments to monitor the use of intellectual property and make decisions about the

I reasonableness of maintaining their legal protection.

I Keywords: scientific and technological development, creation of intellectual property at the expense of public funds,

I. management of intellectual property, codification of rules, agreements, subsidies, grants. 